Article

\title{
Diurnal Energy Balance in a Mango Orchard in the Northeast of Pará, Brazil
}

\author{
Paulo Jorge de Oliveira Ponte de Souza ${ }^{1}$ (iD, Juliana Chagas Rodrigues ${ }^{1}$, \\ Adriano Marlisom Leão de Sousa ${ }^{2}$, Everaldo Barreiros de Souza ${ }^{3}$ \\ ${ }^{1}$ Programa de Pós-Graduação em Agronomia, \\ Instituto Socioambiental e dos Recursos Hidricos, \\ Universidade Federal Rural da Amazônia, Belém, PA, Brazil. \\ ${ }^{2}$ Instituto Socioambiental e dos Recursos Hídricos, \\ Universidade Federal Rural da Amazônia, Belém, PA, Brazil. \\ ${ }^{3}$ Programa de Pós-Graduação em Ciências Ambientais, Instituto de Geociências, \\ Universidade Federal do Pará, Belém, PA, Brazil.
}

Received in December 18, 2017 - Accepted in July 3, 2018

\begin{abstract}
This study aimed to evaluate the diurnal energy balance during the reproductive stage of two growing seasons of a mango orchard in the northeast of Pará, Brazil. Therefore, a micrometeorological tower was installed and instrumented, in the center of the experimental area, to monitor meteorological variables, besides the phenological evaluation of the mango orchard, which was carried out during growing seasons of 2010-2011 (October 2010 to January 2011) and of 2011-2012 (September 2011 to January 2012). The energy balance was obtained by the bowen ration technique, and the available energy partitioned into heat flux to the ground, sensible heat and latent heat. The amount of rainfall was crucial to the partition of the net radiation in the energy balance components. It provided the variation in the consumption of available energy between $69 \%$ and $78 \%$ as latent heat flux, and between $23 \%$ and $32 \%$ as sensible heat flux. The heat flux to the ground was small, representing less than $1 \%$ of the net radiation, showing that the mango orchard exhibits good soil cover preventing large variations in soil heating.
\end{abstract}

Keywords: bowen ratio, energy partition, latent heat flux.

\section{Balanço de Energia Diurno em um Pomar de Mangueiras no Nordeste do Pará, Brazil}

\begin{abstract}
Resumo
Este estudo teve como objetivo avaliar o balanço energético diurno na fase reprodutiva durante duas safras de um pomar de mangueiras no nordeste paraense, Brasil. Para isso, uma torre micrometeorológica foi instalada e instrumentada no centro da área experimental para o monitoramento de variáveis meteorológicas, além do acompanhamento da fenologia das mangueiras, os quais ocorreram durante as safras 2010-2011 (outubro de 2010 a janeiro de 2011) e 2011-2012 (setembro de 2011 a janeiro de 2012). O balanço de energia foi obtido através da técnica da razão de Bowen, e energia disponível particionada em fluxos de calor para o solo, de calor sensível e de calor latente. A quantidade de chuvas foi determinante para a partição da radiação líquida nas componentes do balanço de energia, proporcionando a variação do consumo da energia disponível entre $69 \%$ e $78 \%$ como fluxo de calor latente, e entre $23 \%$ e $32 \%$, como fluxo de calor sensível. O fluxo de calor para o solo foi pequeno, representando menos de $1 \%$ do saldo de radiação, demonstrando que o pomar de mangueiras apresenta boa cobertura do solo impedindo grandes variações no aquecimento do solo.
\end{abstract}

Palavras-chave: razão de bowen, partição de energia, fluxo de calor latente.

Corresponding author: Paulo Jorge de Oliveira Ponte de Souza, paulojorge_oliveira@globomail.com. 


\section{Introduction}

Due to the importance of solar radiation for biophysical processes in the soil-plant-atmosphere (Cosentino et al., 2016; Demotes-Mainard et al., 2016), the quantification of net radiation components and the energy fluxes in vegetated surfaces have been the subject of several researches in different crops, such as sugar cane cultivation (Azevedo et al., 2014), in Capim, Paraíba; vineyards (Pedro Júnior et al., 2015), in São Roque, São Paulo; and in pasture (Webler et al., 2013), in Ouro Preto do Oeste, Rondônia.

Depending on the type of ecosystem involved, there is a different pattern of surface interaction with the atmosphere, which is responsible for controlling and regulating the local climate (Costa et al., 2007). The vegetative cover is a determinant factor in the energy balance of the surface, with a greater variation in proportions of sensible heat flux $(H)$, latent heat flux $(L E)$ and heat flux in the ground $(G)$ when compared to the net radiation (Rnet) during the cycle of annual crops, for example (Lima et al., 2011; Souza et al., 2012).

On the other hand, perennial crops, such as mango tree, when they reach maturity, tend to consume most of the available energy as latent and sensible heat flux (Teixeira and Bastiaanssen, 2012), while small proportions are designed to the ground heat flow, due to the size of the trees which provides greater interception of solar radiation and soil cover (Silva et al., 2007). The partition of the energy balance for mango trees in Petrolina, Pernambuco, showed that the components balance had an average of $80.82 \%$ for LE/Rnet, $13.88 \%$ for H/Rnet and $-0.21 \%$ for G/Rnet (Borges et al., 2008; Teixeira et al., 2008a, b).

From the agronomic point of view, results of Silva et al. (2009) indicate that irrigated mango orchards presented higher productivity when submitted to water supplies corresponding to $90 \%$ of the crop demand, indicating a more efficient use of water than a $100 \%$ of water supply. In the irrigated agriculture practice, knowledge of the crop evapotranspiration is considered fundamental (Campos et al., 2008), which can be estimated through knowledge of energy in the form of latent heat (Souza et al., 2016), which would help in the management and use of this technology in the region due to the scarcity of studies of this nature.

The bowen ratio method has been extensively used to estimate the energy fluxes as well as the evapotranspiration in both annual plant and perennial crops, and its results have shown a reasonable accuracy when compared to results obtained by lysimeters considering, however, conditions in which there is no advective effect (Silva, et al., 2005).

The surface heterogeneity is an important factor to consider because it directly influences the aerodynamic roughness (Tsai et al., 2010) as well as the viability of the bowen ratio method (Friedrich et al., 2000) since during the transition of a surface less rough to a more rough one, there is a development of a new boundary layer with the charac- teristics of the new surface, below the boundary layer that was in equilibrium with that previous surface (Monteith and Unsworth, 1990).

The existence of advection and the presence of heterogeneous surfaces make it unfeasible to consider similarity between the turbulent coefficients of heat diffusion $\left(\mathrm{k}_{\mathrm{h}}\right)$ and water vapor $\left(\mathrm{k}_{\mathrm{w}}\right)$ adopted in the method (Gavilan and Berengena, 2007), having a much greater effect when the area of interest does not have enough fetch length (Todd et al., 2000).

However, surface heterogeneity only has a significant effect in situations where one type of cover exceeds, in size, the other, in large proportions (Friedrich et al., 2000). Even in advective conditions, the ratio $\mathrm{kh} / \mathrm{kw}$ is not much different from 1 (Laubach et al., 2000) when it is adopted a minimum fetch of $100 \mathrm{~m}$ (Gavilan and Berengena, 2007).

Some studies have already been carried out in perennial and discontinuous vegetable communities with good performance of the bowen ratio method, such as in orange orchards (Consoli and Papa, 2013) and mango orchards (Silva et al., 2007; Teixeira et al., 2008b, Teixeira and Bastiaanssen, 2012).

Considering the importance of the mango tree in the national culture scenery, the incipient of agrometeorological studies on this crop and the potential for expansion in mango cultivation in the Amazon, this study aimed to evaluate the diurnal energy balance on the reproductive phase in an orchard of mango trees in northeast Para, Brazil.

\section{Material and Methods}

The study was carried out in a mango orchard cv. Tommy Atkins located at the Cuiarana experimental site, which belongs to the Amazon Federal Rural University (UFRA), Salinópolis city, Pará $\left(00^{\circ} 39^{\prime} 50,50^{\prime}\right.$ S, $47^{\circ} 17^{\prime} 04,10^{\prime \prime} \mathrm{W}$ and $17 \mathrm{~m}$ altitude). The region has an annual daily mean temperature of $27^{\circ} \mathrm{C}$; an annual daily mean relative humidity of $82.5 \%$; an average sunshine hours of $2.100 \mathrm{~h}$ and a total annual rainfall of $2.750 \mathrm{~mm}$, concentrated between January and June (Ramos et al., 2009), a period that comprises part of the vegetative stage of the mango trees in the study area (Rodrigues et al., 2013).

The orchard was established in 1993 for commercial purposes, with spacing intervals of $10.0 \times 10.0 \mathrm{~m}(100$ plants $\mathrm{ha}^{-1}$ ) and pruning performed annually in the vegetative stage. The orchard was composed of cv. Tommy Atkins, with an average height of $6 \mathrm{~m}$, a mean leaf area index (LAI) of 6.7 and a mean diameter of the canopy between lines and plants of $8.5 \mathrm{~m}$. In addition, the trees were cultivated under a dryland farming system in a total area of 25 ha. In the center of the orchard, an area of one hectare was demarcated for the study, in which samplings of meteorological and phenological data were carried out throughout the production cycle in the growing season of 20102011 (October 2010 to January 2011) and 2011-2012 (September, 2011 to January, 2012), which were named as crop 
1 and crop 2, respectively. During the trial, crop practices inherent in the culture were maintained. The soil between the row of the orchard was covered by grasses and small vegetation that were controlled by managing and cleaning of the area.

At the center of the experimental area, a micrometeorological tower of $10 \mathrm{~m}$ height was installed and instrumented with a fetch of more than 1:100 in the prevailing wind direction. Thereby, advective effects which, eventually, had interfered on measurements carried out in the orchard could be avoided (Gavilán and Berengena, 2007). The sensors used were connected to a data logger (CR10X, Campbell Scientific) and a multiplexer (AM16/32A, Campbell Scientific), which performed samplings every $10 \mathrm{~s}$ and the recording of averages and totals every $10 \mathrm{~min}$.

The reproductive cycle of the mango orchards was divided into four phenological phases, which are: flowering, fruit fall, fruit formation and fruit maturing. It was monitored according to Rodrigues et al. (2013). During the crop 1 , the flowering occurred between October 10th and November 4th, 2010; the fruit fall ensued between November 5th and December 6th, 2010; the fruit formation appeared between December 7th, 2010 and January 2nd, 2011 and fruit maturing developed between January 3rd and January 27 th, 2011, totaling 110 days of cycle. On the other hand, in the crop 2, the flowering occurred between September 20th and October 15th, 2011; the fruit fall ensued between October 16th and November 17th, 2011; the fruit formation appeared between November 18th and December 14th, 2011 and the fruit maturing developed between December 15th, 2011 and January 9th, 2012, totaling 112 days.

The global solar radiation $(R g)$ was monitored using a pyranometer (CMP3, Kipp \& Zonen), while the net radiation (Rnet) was obtained through a net radiometer (NRLite, Kipp \& Zonen) installed at $10.0 \mathrm{~m}$ and $8.5 \mathrm{~m}$ height, respectively. The meteorological measurements started to be made few days before the flowering of the first growing season, finishing just after its final harvest. Due to the unavailability of the sensors there were not made any measurements during vegetative stage of the second growing season, which started close to its reproductive stage.

The components of energy balance were obtained through the Eq. (1):

$$
\text { Rnet }=H+L E+G
$$

With all variables in $\mathrm{MJ} \mathrm{m}^{-2} \mathrm{day}^{-1}$. The heat flux to the ground was obtained by only two flowmeters (HFP01SCL, Hukseflux), installed in the north-south and east-west directions at $0.10 \mathrm{~m}$ depth beneath a mango tree. Once the canopy cover almost totally soil in the experimental area, it is expected to $\mathrm{G}$ varies between 5 and $10 \%$ (Kustas et al., 2000), which is why the flow plates were not installed near the surface. Besides that, according to Borges et al. (2008), although there is a significant difference in the soil heat flux between the values corrected and not corrected by the en- ergy stored in the layer above it, the results obtained for a mango orchard with a canopy more spaced, showed that the heat stored above the flow plate does not influence the energy balance neither the water consumption of the orchard, which indicate that there is no difference between installing the sensor at 0.02 or $0.08 \mathrm{~m}$ below the ground.

This equation does not consider some components, such as the energy stored in the tree canopies and the energy used in the photosynthetic process, due to its little representation in relation to the net radiation (Rnet), and the difficulty of its acquisition (Borges et al., 2008), respectively. The analysis of the energy balance was performed considering only the daytime (Rnet-G>0) since it represents the most accurate way and with smallest error in studies related to energy and evapotranspiration balance (Oliveira and Leitão, 2000).

The latent and sensible heat flux were obtained from the energy balance, such as estimated in Souza et al. (2012) through the Bowen ratio $(\beta)$. This ratio was obtained through relationships of vertical transport of heat and water vapor, considering that there is an equality in the turbulent transport coefficients of the sensible heat and water vapor flux, $K_{H}$ e $K_{W}$, respectively (Arya, 2001), that is:

$$
\beta=\frac{H}{L E} \frac{C p}{\lambda} \frac{\Delta T}{\Delta q}=\frac{C p P}{\lambda \cdot 0,622} \frac{\Delta T}{\Delta e}=\gamma \frac{\Delta T}{\Delta e}
$$

In which $C p$ is the specific heat of air at constant pressure $\left(\mathrm{J} \mathrm{kg}^{-1}{ }^{\circ} \mathrm{C}^{-1}\right), \lambda$ is the latent heat of evaporation $\left(\mathrm{J} \mathrm{kg}^{-1}\right)$, $\Delta q$ is the specific humidity vertical difference $\left(\mathrm{g} \mathrm{kg}^{-1}\right) P$ is the local atmospheric pressure $(\mathrm{kPa}), \gamma$ is the psychrometric coefficient $\left(\mathrm{kPa}^{\circ} \mathrm{C}\right)$, and $\Delta T$ and $\Delta e$ are the average temperature of the air $\left({ }^{\circ} \mathrm{C}\right)$ and water vapor pressure $(\mathrm{kPa})$ differences between two levels, respectively. The air temperature and relative humidity were obtained through thermohygrometers (HMP45A, Vaisala) installed on two levels, at $0.5 \mathrm{~m}$ and $2.0 \mathrm{~m}$ above the canopy of the mango trees.

The values of $\beta$ underwent by quality control, attending the criteria adopted by Perez et al. (1999). This method is based on an analytical method of determination in consistency of observed signals in the flux-gradient relationship between the components, and which $\beta$ values around -1 may be dropped depending on the accuracy of temperature and humidity measurements, which were considered, for the type of sensor used, as being $\pm 0.2{ }^{\circ} \mathrm{C}$ for the temperature $(\delta \Delta T)$ and $\pm 2 \%$ for relative humidity $(\delta \Delta e)$ of the air (Souza et al., 2012). After quality control, the gap filling of energy flow data was done due to the correlation between $(H+L E)$ with the available energy $($ Rnet $+G)$ for each phase (Teixeira and Bastiaaseen, 2012) according to the correlations obtained from the data for each phases and both crop period (Table 1).

The LE component was, then, obtained by $\beta$ (Eq. (3)) and $H$ by the residue of the energy balance. 
Table 1 - Coefficient of the regression analysis from hourly correlation between $\mathrm{H}+\mathrm{LE}$ (Y coordinate) and Rnet $+\mathrm{G}$ (X coordinate), both in W. $\mathrm{m}^{-2}$, during the production cycle of the mango trees cv. Tommy Atkins, Salinópolis, Pará.

\begin{tabular}{lccc}
\hline Phases & Coefficient & Growing season 1 & Growing season 2 \\
\hline 1 & $\mathrm{a}$ & 0.87 & 4.733 \\
& $\mathrm{~b}$ & 1.012 & 0.989 \\
& $\mathrm{R}$ & 0.999 & 0.999 \\
& $\mathrm{R}$ & 2.424 & 5.206 \\
& $\mathrm{a}$ & 0.998 & 0.99 \\
3 & $\mathrm{~b}$ & 0.998 & 0.999 \\
& $\mathrm{R}^{2}$ & 2.828 & 5.652 \\
& $\mathrm{a}$ & 0.996 & 0.989 \\
4 & $\mathrm{~b}$ & 0.999 & 0.999 \\
& $\mathrm{R}^{2}$ & 8.91 & 4.023 \\
& $\mathrm{a}$ & 0.999 & 0.993 \\
& $\mathrm{~b}$ & 0.998 & 0.999 \\
\hline
\end{tabular}

$$
L E=\frac{\text { Rnet }-G}{1+\beta}
$$

The experimental design of this study was fully casualized. The components of radiation and energy balance were represented through descriptive statistics of the samples. Student's $t$-test was used at a probability level of $5 \%$ to indicate significant differences between the aver- ages of the energy componentes oberved during the two years.

\section{Results and Discussion}

Data quality control resulted in gaps in the bowen ratio series which corresponded to $10.7 \%$ of the whole series during crop 1 in all phases. The gaps occurred more frequently between 06 and $09 \mathrm{~h}$ in the morning $(22 \%$ of the data), whereas between 10 and $16 \mathrm{~h}$, gaps were observed in only $6.6 \%$ of the data series.

In relation to diurnal gaps at each phase of crop 1, there was a large occurrence of failures before 07 and after $17 \mathrm{~h}$ in more than $70 \%$ of the days for all phases (Fig. 1). Between these interval, gaps occurred in a maximum of $20 \%$ of the days until the fruit fall phase, mainly before $08 \mathrm{~h}$ in the morning (Fig. 1b).

On the other hand, during the formation and maturing phases of crop 1, the quality control caused data gaps in about $30 \%$ of the days used, between 10 and $16 \mathrm{~h}$ in the formation phase (Fig. 1c), and up to $60 \%$ of the days in the maturing phase, regardless of the time (Fig. 1d).

The elimination of data in crop 1 provided the occurrence of 22 days with less than $1 / 3$ of data throughout the day from the fruit formation phase, of which 12 days were completely discarded, 3 days within the formation phase and 9 days within the maturing phase.

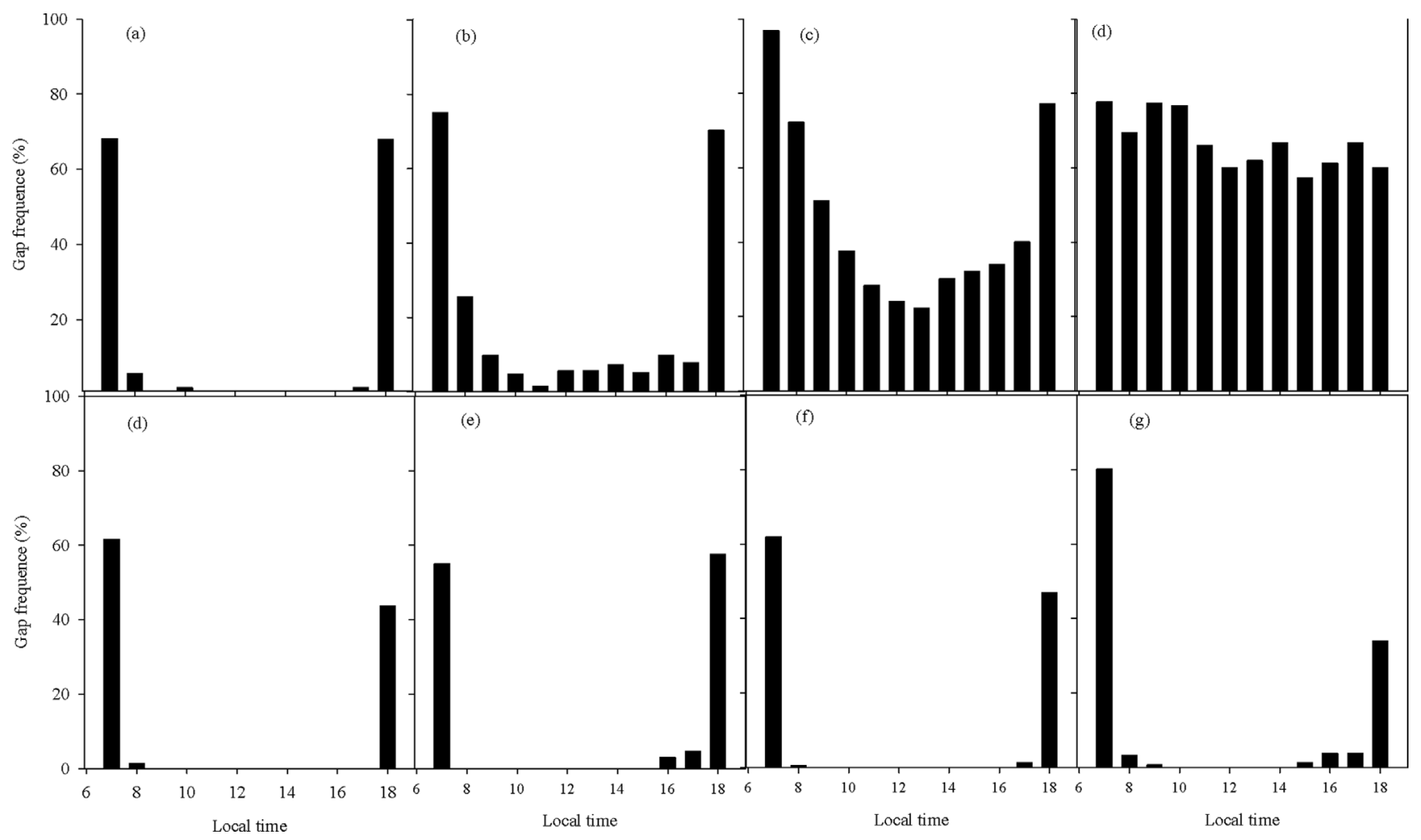

Figure 1 - Gap frequency after data quality control in both crop seasons, during Flowering (a-d), Fruit Fall (b-e), Fruit formation (c-f) and Fruit maturing $(\mathrm{d}-\mathrm{g})$. 
This occurred because the formation and maturing phases coincided with the beginning of the rainy season, creating atmospheric conditions not recommended for the bowen ratio method (Souza et al., 2016), since the accuracy of the method decreases when the air temperature and humidity gradients are less developed as a consequence of a more stable vertical air temperature conditions (Teixeira and Bastiaanseen, 2012).

In crop 2, however, the failures were smaller, not exceeding $5 \%$ in the whole data series, with no discard of days. Similar to that observed in crop 1, major failures were observed after quality control in periods prior to $7 \mathrm{a} . \mathrm{m}$. and after 17:30 $\mathrm{h}$ for all phases (Fig. 1), with no significant gaps at other time intervals. The data missing during the day in both growing seasons were filled according to the correlation obtained for each phase (Table 1).

During the reproductive cycle of the mango orchard, the daily average air temperature ranged between 23.1 and $28.8^{\circ} \mathrm{C}$ (Figs. 2a and 2b). Therefore, the crop development did not suffer thermal limitation, since the interval between $24^{\circ} \mathrm{C}$ and $30^{\circ} \mathrm{C}$ is considered to be optimal for the development of mango trees (Schaffer et al., 2009). However, frequent occurrence of air temperatures above $30{ }^{\circ} \mathrm{C}$ were noticed, especially during flowering and fruit fall sub- phases. This is due to the climate in the region associated with a lower presence of cloudiness at this time of the year.

In the fruit formation phase, the total precipitation was around of $90 \mathrm{~mm}$ in the crop 1 and only $15 \mathrm{~mm}$ in the crop 2; and during the maturing phase, the total rainfall was $324 \mathrm{~mm}$ in crop 1 and $22 \mathrm{~mm}$ in crop 2 (Figs. 2c and 2d), which suggest that the amount of rainfall in the crop 2 was below the climatological normals of the region (Ramos et al., 2009).

It is noticeable a great variability of solar radiation $(R g)$ during the experiment due to the transition of the less rainy season to the rainy season. The values ranged from $7.91 \mathrm{MJ} \mathrm{m}^{-2}$ day $^{-1}$ (maturing) to $26.2 \mathrm{MJ} \mathrm{m}^{-2} \mathrm{day}^{-1}$ (flowering) in the crop 1 (Figs. 2c) and from $13.96 \mathrm{MJ} \mathrm{m}^{-2}$ day $^{-1}$ (flowering) to $26.7 \mathrm{MJ} \mathrm{m}^{-2}$ day $^{-1}$ (fruit fall) in the crop 2 (Figs. 2d). For the phases of fruit formation and fruit maturing, there was a reduction of global solar irradiance due to the increased rainfall observed and the increased cloudiness.

Table 2 shows the average daily data of solar irradiance and net radiation, in $\mathrm{MJ} \mathrm{m}^{-2}$, for each phenological phase of the mango orchard during the first growing season (crop 1 ) and the second growing season (crop 2). The net radiation was positive and followed the trend of global solar irradiance variation, which represents the component of

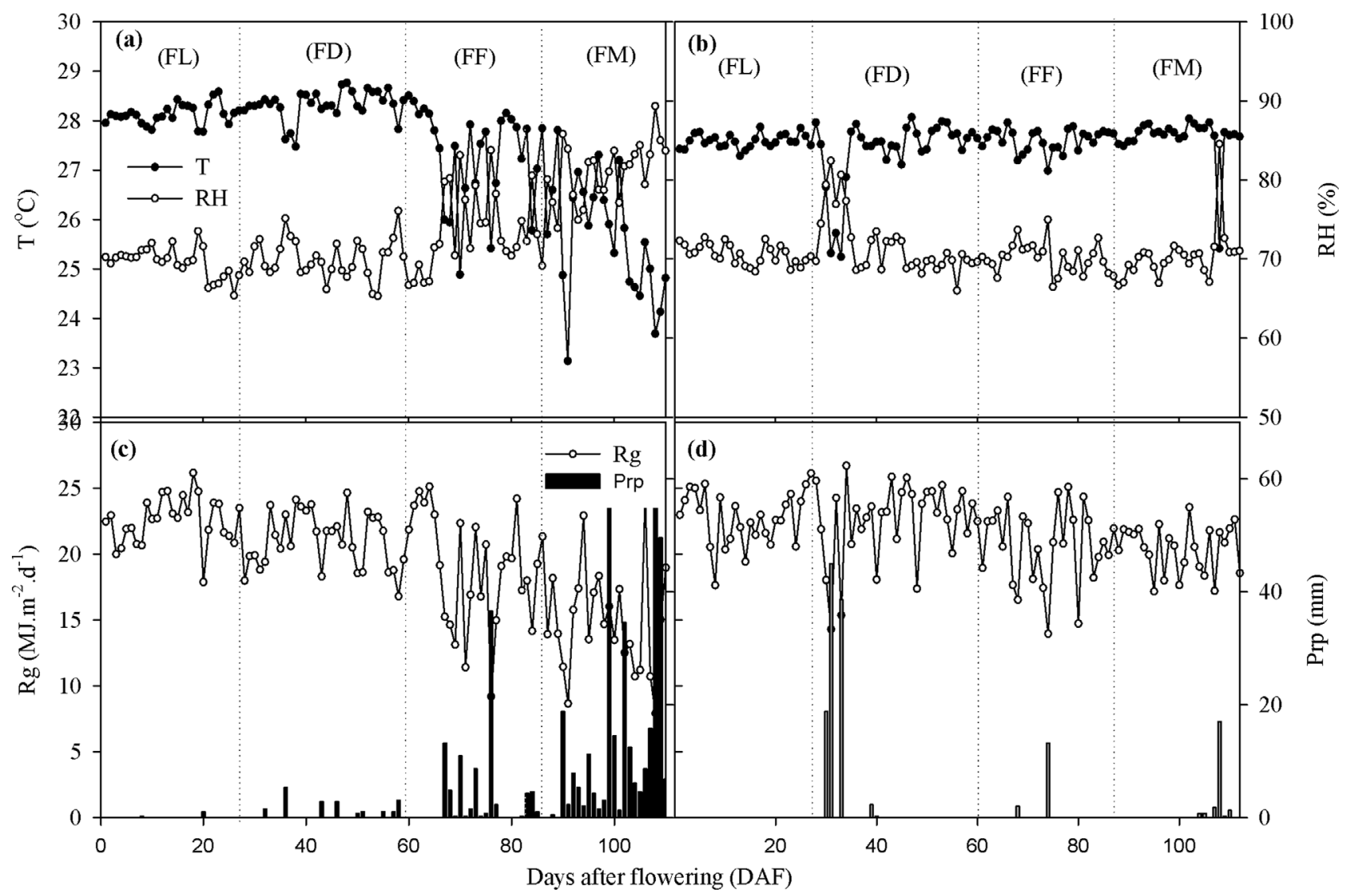

Figure 2 - Temporal variability of meteorological conditions during the reproductive stage in a mango orchard cv. Tommy Atkins, in the seasons 1 (a and c) and 2 (b and d) at Salinópolis, Pará. (FL) Flowering, (FD) Fruit Fall, (FF) Fruit formation and (FM) Fruit maturing. 
Table 2 - Daily average of global solar irradiance and net radiation during the production cycle of the mango trees cv. Tommy Atkins, Salinópolis, Pará.

\begin{tabular}{|c|c|c|c|c|c|c|c|c|c|}
\hline \multirow[t]{2}{*}{ Phases } & \multirow{2}{*}{$\begin{array}{l}\text { Variable } \\
\left(\mathrm{MJ} \cdot \mathrm{m}^{-2}\right)\end{array}$} & \multicolumn{4}{|c|}{ Growing season 1} & \multicolumn{4}{|c|}{ Growing season 2} \\
\hline & & Mean & Min. & Max. & SD & Mean & Min. & Max. & $\mathrm{SD}$ \\
\hline \multirow[t]{2}{*}{1} & $\mathrm{Rg}$ & 22.4 & 18.3 & 26.7 & 2.5 & 22.6 & 17.6 & 25.2 & 2.0 \\
\hline & Rnet & 12.4 & 9.3 & 15.0 & 1.5 & 12.2 & 8.8 & 14.2 & 1.4 \\
\hline \multirow[t]{2}{*}{2} & $\mathrm{Rg}$ & 21.4 & 16.9 & 25.9 & 2.4 & 22.6 & 14.3 & 26.7 & 3.1 \\
\hline & Rnet & 11.6 & 8.3 & 14.1 & 1.5 & 12.2 & 5.8 & 15.1 & 2.2 \\
\hline \multirow[t]{2}{*}{3} & $\mathrm{Rg}$ & 17.4 & 6.8 & 24.8 & 5.6 & 20.7 & 14.0 & 25.1 & 3.0 \\
\hline & Rnet & 9.3 & 2.7 & 14.3 & 3.5 & 11.0 & 6.2 & 14.0 & 2.1 \\
\hline \multirow[t]{2}{*}{4} & $\mathrm{Rg}$ & 15.0 & 4.1 & 24.4 & 4.8 & 20.6 & 17.2 & 23.6 & 1.7 \\
\hline & Rnet & 7.9 & 1.3 & 14.9 & 3.3 & 11.0 & 8.5 & 13.1 & 1.2 \\
\hline
\end{tabular}

Phenological phases: (1) Flowering; (2) Fruit fall; (3) Fruit formation; and (4) Fruit maturing. (Min.) minimum; (Max) maximum; (SD) Standard deviation.

greater influence on the net radiation, with some differences between the phenological phases. The phases of flowering and fruit fall showed higher values of the incident solar radiation, while in the following phases the values were relatively lower. This fact is explained due to the higher amount of rainfall and increased cloudiness during the final phases of the cycle (fruit formation and fruit maturing), which led to lower availability of incident solar radiation.

The mean daily total of global solar radiation varied from $22.36 \mathrm{MJ} \mathrm{m}^{-2}$ at the beginning of the cycle to $14.98 \mathrm{MJ} \mathrm{m}^{-2}$ at the end of first growing season, that is a reduction of $33 \%$. In the second growing season, the solar radiation decreased by only $8.8 \%$. Similarly, the net radiation suffered decreases through the cycle due to the reduction in the energy availability of about $35 \%$ and $10.4 \%$ in the crops 1 and 2, respectively.

Researches that analyzed the seasonal variation of the net radiation in areas in the Amazon (Souza et al., 2013; Webler et al., 2013) observed that the radiation components show greater values during the dry season and lower values over the rainy season. This difference occurs because at the rainy season, days have big changes in cloud cover; therefore, cloudy periods represent phases with lower availability of energy, which cause, thereby, variation in the component values of the net radiation.

The results of the energy balance components shown in Fig. 3 and Table 3 refer only to the daytime period
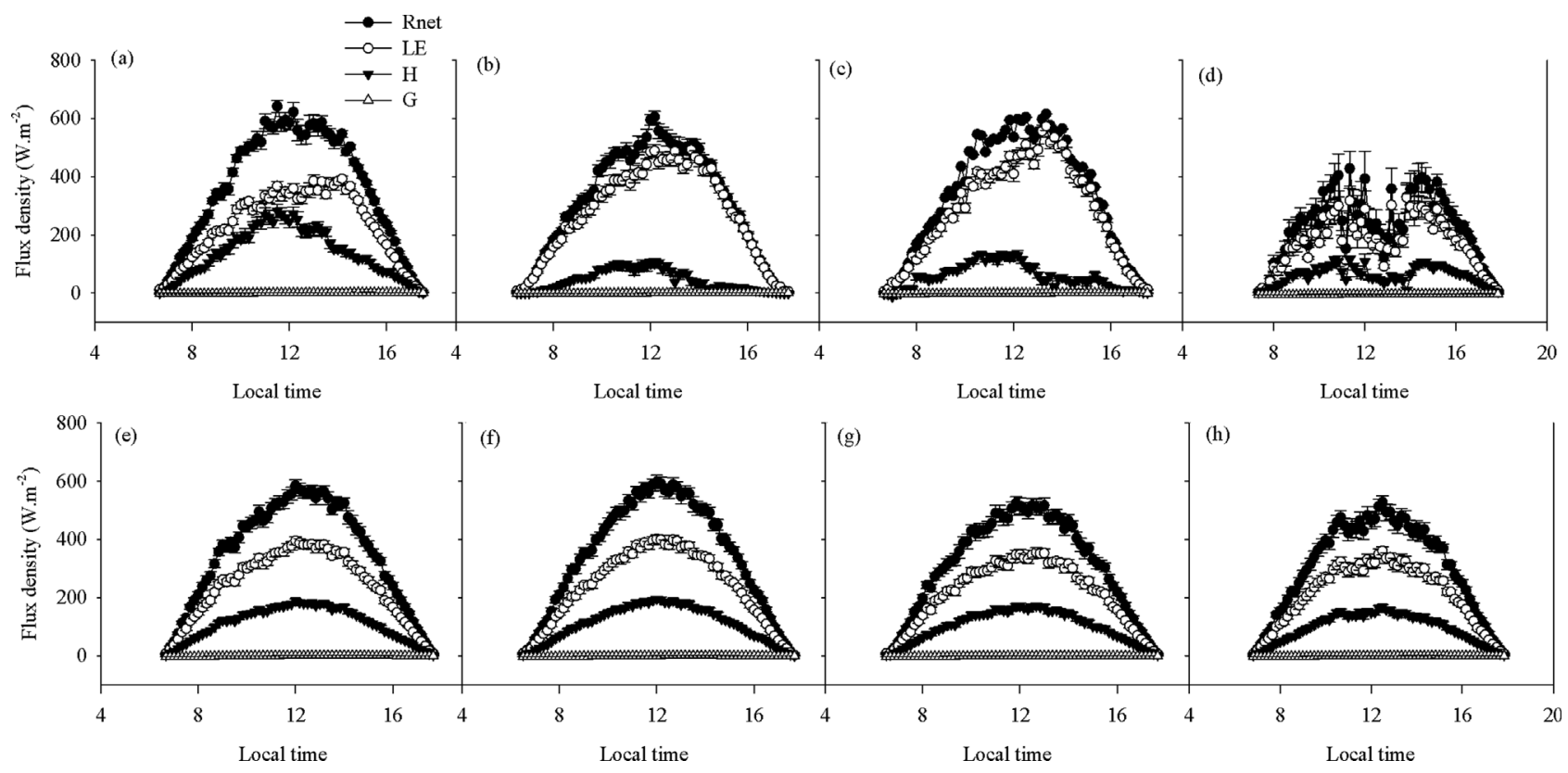

Figure 3 - Mean hourly variability of the components of energy balance in the daily period during the crop 1 (a to d) and 2 (e to h) for phenological phases of (a) and (e) flowering, (b) and (f) Fruit Fall, (c) and (g) Fruit formation and (d) and (h) Fruit maturing, respectively, in a mango orchard cv Tommy Atkins, Salinópolis, Pará. 
Table 3 - Ratio of latent heat flux (LE), sensitive heat flux (H) and flux to the ground $(\mathrm{G})$ with the energy balance (Rnet) during daily time period, in a mango orchard cv. Tommy Atkins, Salinópolis, Pará.

\begin{tabular}{|c|c|c|c|c|c|c|}
\hline \multirow[t]{2}{*}{ Phases } & \multicolumn{2}{|c|}{ LE/Rnet } & \multicolumn{2}{|c|}{$\mathrm{H} /$ Rnet } & \multicolumn{2}{|c|}{ G/Rnet } \\
\hline & Crop season $1(\%)$ & Crop season $2(\%)$ & Crop season $1(\%)$ & Crop season $2(\%)$ & Crop season $1(\%)$ & Crop season $2(\%)$ \\
\hline Flowering & $65.04 *$ & $68.97 *$ & $36.26^{*}$ & $31.67 *$ & $0.17^{*}$ & $-0.65^{*}$ \\
\hline Fruit fall & $88.13^{*}$ & $68.35^{*}$ & $12.33^{*}$ & $31.99 *$ & $-0.14 *$ & $-0.35^{*}$ \\
\hline Formation & $83.46^{*}$ & $68.51^{*}$ & $16.85^{*}$ & $32.04 *$ & $-0.32 *$ & $-0.49 *$ \\
\hline Maturing & $76.08 *$ & $69.51 *$ & $26.67 *$ & $31.09 *$ & $-2.75 *$ & $-0.61 *$ \\
\hline Average & 78.18 & 68.83 & 23.03 & 31.69 & -0.76 & -0.52 \\
\hline
\end{tabular}

* Means in the same lines differ by t-test at $5 \%$ of probability.

(Rnet- $G>0)$. When considering Rnet values for a $24 \mathrm{~h}$ period, the error associated with the $L E$ calculation and the evapotranspiration estimation and, consequently, the correct application in irrigation water depth can reach 2.2 MJ.m ${ }^{-2}$.day ${ }^{-1}$ (Oliveira and Leitão, 2000). The same procedures are applied to other components of energy balance.

During the flowering in the crop 1, it was verified a more homogeneous partition of Rnet between $L E$ and $H$ throughout the day. This was due to the lack of precipitation during this sub-phase, which resulted in lower water supply (Fig. 3a). In fruit fall phase the Rnet was nearly exhausted by the $L E$, mainly between 14 and $18 \mathrm{~h}$ (Fig. 3b). The change in energy consumption is justified by some rainfall that occurred over this period (Fig. 1c), which mostly had concentrated between 1 and $8 \mathrm{~h}$. Thereby, increasing water availability and providing favorable conditions for the consumption of net radiation in the form of latent heat.

A similar analysis was made for the fruit formation (Fig. 3c), since both occurred in the transition between the dry and rainy period. The intensification of rainfall and the increase of cloudiness during the maturing phase (Fig. 2c) provided lower availability of $R g$ at midday. It promoted the reduction of energy used in the form of latent heat and air heating. However, due to the increase in water availability, the Rnet remained to be more consumed by $L E$ in relation to $H$ and $G$, although in a lesser magnitude.

The crop 2 showed less variability in the time scale regarding to the energy balance components between the different phenological phases. This occurred due to the less variability in meteorological conditions that occurred in this period. Despite the greater scarcity of rainfall in the second growing season (crop 2), there was a higher consumption of Rnet by the $L E$ and an important contribution of the $H$ component in the consumption of available energy, while the $G$ did not vary over the phenological phases.

Considering the mango orchards production cycle, there were great variability in the Rnet, $L E$ and $H$ values while the $G$ value remained almost constant in both growing seasons (Table 3 ). In both growing seasons there was high energy consumption in the form of latent heat flux, with a significant effect of the environmental conditions observed in each growing season on the partition when comparing both crop 1 and 2 (t-test, $\mathrm{p}<0.05)$. As observed in Fig. 2 the quantity of rain was higher during crop 1, which could explain the elevated energy consumption by $L E$, on average $10 \%$, when compared to the crop 2 .

During the fruit formation and fruit maturing phases in crop 1, low values of $H$ occurred due to the influence of rain events which contributed to the occurrence of smaller temperature and humidity gradients, which resulted in the reversion of $H$ transport. The rainfall creates stable conditions of air temperature, creating vertical profiles which are more difficult to measure, which make the Bowen method less precise and with high variability (Teixeira and Bastiaanssen, 2012). This suggests the lateral transport of energy from surrounding areas to the mango orchard promoting the effect of advection, which generates an additional source of energy for evapotranspiration. Thereby, this kind of transport is characterized by the occurrence of $L E$ values bigger than Rnet ones (Berlato and Molion, 1981).

During the crop 2, the values of the energy balance components were more stable throughout the entire cycle, with the $L E$ consuming more energy than the $H$ and the $G$ (Table 3). Due to the lack in the rainfall, the energy partition destined to the evapotranspiration process was reduced when compared to the previous crop, reaching an average fraction of $68.8 \%$, while $31.7 \%$ was used for heating the atmosphere $(H)$.

The obtained results differed from other studies on energy balance for the mango cultivation in Brazil. The fraction consumed by latent heat flux (LE/Rnet) at the second growing season $(69 \%)$ was lower than the one obtained by Silva et al. (2007), who found a mean fraction of $76.35 \%$ while Borges et al. (2008), Teixeira et al. (2008a) and Teixeira et al. (2008b) estimated an average ratio of $81.27 \%, 76.79 \%$ and $84.44 \%$, respectively. These two latter studies were performed in Petrolina, Pernambuco, under irrigated conditions. On the other hands, during the first growing season the consumption of energy by latent heat ( $78 \%$ of Rnet) was close to these values probably due to the increased water availability by the rain. 
The fraction consumed by sensible heat flux in both growing seasons (23\% in crop 1 and $31,7 \%$ in crop 2$)$ was greater than those obtained by Borges et al. (2008), by Teixeira et al. (2008a) and by Teixeira et al. (2008b), who estimated a mean ratio of $14.45 \%, 14.31 \%$ and $12.88 \%$, respectively. Other researchers also determined small fractions of the energy directed to the ground (G/Rnet), such as Borges et al. (2008), Teixeira et al. (2008a) and Teixeira et al. (2008b) that found $4.44 \%, 8.90 \%$ and $2.68 \%$ of the energy consumed as heat flux to the ground, respectively.

The type of instruments used by the other authors also contributed to the differences obtained. The Bowen ratio method is based on vertical profiles of air temperature and water vapor pressure, with several measuring instruments such as automatic systems based on a single cooled dew point hygrometer and thermocouple profiles (Silva, et al., 2005; Savage et al., 2009), through integrated sensors of temperature (resistors) and relative humidity (capacitors) (Todd et al., 2000, Savage et al., 2010), or even by simple equipments based on dry and wet bulb thermocouple profiles (Soares et al., 2007).

However, the accuracy and precision of the method in estimating the energy balance depend not only on atmospheric conditions (Teixeira and Bastiaanseen, 2012), or on data quality control method (Soares et al., 2007), but mainly on quality of the data and of the error inherent in the type of sensor used (Savage et al., 2010).

Results from Savage et al. (2010) have shown that even less expensive sensors, similar to the one used in this work, can be adopted in substitution of the most expensive equipment in studies of this nature, maintaining high precision in the estimation of the energy fluxes.

According to the authors, the magnitude of the accuracy of errors generated by a sensor similar to that used in the work is acceptable, providing estimates of sensible heat fluxes with errors (RMSE) of only 8 and $38 \mathrm{Wm}^{-2}$ when compared with results obtained by a dew point generator and an eddy covariance system, respectively. For this, small modifications must be made to the measurement system, such as removal of a protective membrane from the humidity sensor, and the use of 20-min averages of the variables in order to reduce noise in the water vapor pressure data.

Although HMP45 series sensors (Campbell sci) were used, it was not adopted such procedures suggested by Savage et al. (2010), but judging by the same characteristics in the accuracy and precision described by the authors for this type of sensor, it is assumed that the estimates of the fluxes where within an acceptable interval, since the methodology proposed during the quality control eliminated the data that would probably be within the limit of the sensor error.

Besides, the environmental factor was crucial in the comparison of the differences between this research and other ones which addressed the energy balance for the mango orchard cultivation in Brazil. Although this study has been done in the Amazon, the northeast region of Pará presents a defined dry season. During the crop 2, the meteorological variables underwent little changes, mainly, due to the lack of rainfall. According to the data, there were only $141.99 \mathrm{~mm}$ during the 2011/ 2012 growing season. Additionally, this orchard is grown under a dryland farming system, thereby; there is no other hydric source that can support the lack of water.

Despite the studies by Silva et al. (2007), Borges et al. (2008) and Teixeira et al. (2008a, b) were carried out in the northeastern region of Brazil with a semi-arid climate, the experimental area presents an irrigation system that supplies the absence of rainfall, providing a favorable environment for high yields, as well as water support for better utilization of components of the energy balance.

\section{Conclusion}

The partitioning of energy balance during two reproductive phases of a mango orchard under climatic conditions in the northeast of Para state presented similar patterns in both growing season with a $L E / R n$ fraction higher than $70 \%$. The amount of rainfall was determinant in controlling of energy partition, indicating that is possible to increase the use of the energy as latent heat, in order to favor crop evapotranspiration and its productivity if the irrigation is adopted in the absence of rainfall events. The heat fluxes to the ground was small, representing less than $1 \%$ of the net radiation, showing that the mango orchard has good soil cover which prevents large variations in soil heating.

\section{References}

ARYA, S.P. Introduction to micrometeorology. New York: Academic Press, 2001.

AZEVEDO, P.V.; SABOYA, L.M.F.; DANTAS NETO, J.; OLIVEIRA, F.S.; BEZERRA, J.R.C. et al. Disponibilidade energética para a cultura da cana-de-açúcar nos tabuleiros costeiros do estado da Paraíba. Revista Brasileira de Engenharia Agrícola e Ambiental, v. 18, n. 10, p. 1031-1038, 2014.

BATISTA, E.L.S.; ZOLNIER, S.; RIBEIRO, A.; LYRA, G.B.; SILVA, T.G.F. et al. Modelagem do crescimento de cultivares de cana-de-açúcar no período de formação da cultura. Revista Brasileira de Engenharia Agrícola e Ambiental, v. 17, n. 10, p. 1080-1087, 2013

BERLATO, M.A.; MOLION, L.C.B. Evaporação e evapotranspiração. Porto alegre: IPAGRO, 1981.

BORGES, C.J.R.; AZEVEDO, P.V.; SILVA, V.P.R.; CAMPOS, J.H.B.C.; MOURA, M.S.B. et al. Influência do calor armazenado no sistema solo-planta no balanço de energia em pomar de mangueiras. Revista Brasileira de Engenharia Agrícola e Ambiental, 12, 4, 393-399, 2008.

CAMPOS, J.H.B.C.; SILVA, V.P.R.; AZEVEDO, P.V.; BORGES, C.J.R.; SOARES, J.M. et al. Evapotranspiração e produtividade da mangueira sob diferentes tratamentos de irrigação. Revista brasileira de engenharia agrícola e ambiental, v. 12, n. 2,p. 150-156, 2008. 
CONSOLI, S.; PAPA, R. Corrected surface energy balance to measure and model the evapotranspiration of irrigated orange orchards in semi-arid Mediterranean conditions. Irrigation science, 31,1159-1171, 2013.

COSENTINO, S.L.; PATANÈ C.; SANZONE, E.; TESTA, G.; SCORDIA, D. Leaf gas exchange, water status and radiation use efficiency of giant reed (Arundo donax L.) in a changing soil nitrogen fertilization and soil water availability in a semi-arid Mediterranean area. European Journal of Agronomy, v. 72, p. 56-69, 2016.

COSTA, M.H.; YANAGY, S.M.N; SOUZA, P.J.O.P.; RIBEIRO, A.; ROCHA, E.J.P. Climate change in Amazonia caused by soybean cropland expansion, as compared to caused by pastureland expansion. Geophysical Research Letters, v. 34:L07706, 2007.

DEMOTES-MAINARD, S.; PÉRON, T.; COROT, A.; BERTHELOOT, J.; GOURRIEREC, J.L. et al. Plant responses to red and far-red lights, applications in horticulture. Environmental and Experimental Botany, v. 121, p. 4-21, 2016.

FRIEDRICH, K.; MOLDERS, N.; TETZLAFF, G. On the Influence of Surface Heterogeneity on the Bowen-Ratio: A Theoretical Case Study. Theoretical and Applied Climatology, v. 65, p. 181-196, 2000.

GAVILÁN, P.; BERENGENA, J. Accuracy of the Bowen ratio-energy balance method for measuring latent heat flux in a semiarid advective environment. Irrigation Science, v. 25, p. 127-140, 2007.

KUSTAS, W.P.; PRUEGER, J.H.; HATFIELD, J.L.; RAMALINGAM, H.; HIPPS, L.E. Variability in soil heat flux from a mesquitedune site. Agricultural and Forest Meteorology, v. 103, n. 1, p. 249-264, 2000.

LAUBACH, J.; MCNAUGHTON, K.G.; WILSON, J.D. Heat and water vapour diffusivities near the base of a disturbed stable internal boundary layer. Boundary Layer Meteorology, v. 94, p. 23-63, 2000.

LIMA, J.R.S.; ANTONINO, A.C.D.; LIRA, C.A.B.O.; SOUZA, E.S.; SILVA, I.F. Balanço de energia e evapotranspiração de feijão caupi sob condições de sequeiro. Revista Ciência Agronômica, v. 42, n. 1, p. 65-74, 2011.

MONTEITH, J.L.; UNSWORTH, M.H. Principles of environmental physics: Plants, Animals and Atmosphere. $4^{\text {th }} \mathrm{ed}$. Academic Press, 1990.

OLIVEIRA, G.M.; LEITÃO, M.M.V.B.R. Estimativas de evapotranspiração e as consequências devido aos erros na determinação de saldo de radiação e efeitos advectivos. Revista Brasileira de Engenharia Agrícola e Ambiental, v. 4, n. 3, p. 343-347, 2000.

PEDRO JÚNIOR, M.J.; HERNANDES, J.L.; BARDIN-CAMPAROTTO, L.; BLAIN, G.C. Balanço de energia e consumo hídrico de vinhedo de 'Cabernet Franc'. Bragantia, v. 74, n. 2, p. 234-238, 2015.

PEREIRA, A.R.; ANGELOCCI, L.R.; SENTELHAS, P.C. Agrometeorologia: fundamentos e aplicações práticas. Guaíba: Agropecuária, 2002.

PEREZ, P.J.; CASTELLVI, F.; IBAÑEZ, M.; ROSELL, J.I. Assessment of reliability of Bowen ratio method for partitioning fluxes. Agricultural and Forest Meteorology, v. 97, n. 3, p. 141-150, 1999.
RAMOS, A.M.; SANTOS, L.A.R.; FORTES, L.T.G. Normais climatológicas do Brasil 1961-1990. Brasília: INMET, 2009.

RODRIGUES, J.C.; SOUZA, P.J.O.P.; LIMA, R.T. Estimativa de temperaturas basais e exigência térmica em mangueira no nordeste do estado do Pará. Revista Brasileira de Fruticultura, v. 35, n. 1, p. 143-150, 2013.

SAVAGE, M.J.; EVERSON, C.S.; METELERKAMP, B.R. Bowen ratio evaporation measurement in a remote montane grassland: Data integrity and fluxes. Journal of Hidrology, v. 376, p. 249-26, 2009.

SAVAGE, M.J. Field evaluation of polymer capacitive humidity sensors for Bowen ratio energy balance flux measurements. Sensors, v. 10, n. 8, p. 7748-7771, 2010.

SCHAFFER, B.; URBAN, L.; LU, P.; WHILEY, A.W. Ecophysiology. In: LITZ, R.E. The mango: botany, production e uses (p. 170-209). Wallingford: CABI Publishing, 2009.

SILVA, L.D.B.; FOLEGATTI, M.V.; VILLA NOVA, N.A. Evapotranspiração do Capim Tanzânia Obtida Pelo Método de Razão de Bowen e Lisímetro de Pesagem. Engenharia Agrícola, v. 25, n. 3, p. 705-712, 2005.

SILVA, V.P.R.; AZEVEDO, P.V.; SILVA, B.B. Surface energy fluxes and evapotranspiration of a mango orchard grown in a semiarid environment. Agronomy Journal, v. 99, p. 13911396, 2007.

SILVA, V.P.R.; CAMPOS, J.H.B.C; AZEVEDO, P.V. Water-use efficiency and evapotranspiration of mango orchard grown in northeastern region of Brazil. Scientia Horticulturae, v. 120, p. 467-472, 2009.

SOARES, J.M.; AZEVEDO P.V.; SILVA, B.B. Bowen ratioenergy balance associated errors in vineyards under dripping irrigation. Revista Brasileira de Meteorologia, v. 22, n. 2, p. 233-240, 2007.

SOUZA, P.J.O.P.; RIBEIRO, A.; ROCHA, E.J.P.; FARIAS, J.R.B.; SOUZA, E.B. Sazonalidade no balanço de energia em áreas de cultivo de soja na Amazônia. Bragantia, v. 71, n. 4, p. 548-557, 2012.

SOUZA, P.J.O.P.; ORTEGA-FARIAS, S.; ROCHA, E.J.P.; SOUSA, A.M.L.; SOUZA, E.B. Consumo hídrico da soja no nordeste Paraense. Irriga, v. 01, n. 01 (edição especial irrigação), p. 218-231, 2016.

SOUZA, P.J.O.P.; RODRIGUES, J.C.; SOUSA, A.M.L.; LIMA, R.T.; ROCHA, E.J.P. et al. Water requirement estimate for the reproductive period of mango orchads in the northeast of the state of Pará, Brazil. Revista brasileira de fruticultura. v. 38, n. 3, p. 1-12, 2016

TEIXEIRA, A.H.C.; BASTIAANSSEN, W.G.M. Five methods to interpret field measurements of energy fluxes over a micro-sprinkler-irrigated mango orchard. Irrigation Science, v. 30, p. 13-28, 2012.

TEIXEIRA, A.H.C.; BASTIAANSSEN, W.G.M.; AHMAD, M.D.; MOURA, M.S.B.; BOS, M.G. Analysis of energy fluxes and vegetation-atmosphere parameters in irrigated and natural ecosystems of semi-arid Brazil. Journal of Hydrology, v. 362, n. 1, p. 110-127, 2008 a.

TEIXEIRA, A.H.C.; BASTIAANSSEN, W.G.M.; MOURA, M.S.B.; SOARES, J.M.; AHMAD, M.D. et al. Energy and water balance measurements for water productivity analysis in irrigated mango trees, northeast Brazil. Agricultural and Forest Meteorology, v. 148, p. 1524-1537, 2008 b. 
TODD, R.W.; EVETT, S.R.; HOWELL, T.A. The Bowen ratio-energy balance method for estimating latent heat flux of irrigated alfalfa evaluated in a semi-arid, advective environment. Agricultural and Forest Meteorology, v. 103, n. 1, p. 335-348, 2000.

TSAI, J.L.; TSUANG, B.J.; LU, P.S.; CHANG, K.H.; YAO, M.H. et al. Measurements of Aerodynamic Roughness, Bowen Ratio, and Atmospheric Surface Layer Height by Eddy Covariance and Tethersonde Systems Simultaneously over a Heterogeneous Rice Paddy. Journal of hydrometeorology, v. 11, p. 452-466, 2010.

WEBLER, A.D.; GOMES, J.B.; AGUIAR, R.G.; ANDRADE, N.L.R. et al. AGUIAR, L.J.G. Mudanças no uso da terra e o particionamento de energia no sudoeste da Amazônia. Revista Brasileira de Engenharia Agrícola e Ambiental, v. 17, n. 8, p. 868-876, 2013.

This is an Open Access article distributed under the terms of the Creative Commons Attribution Non-Commercial License which permits unrestricted non-commercial use, distribution, and reproduction in any medium provided the original work is properly cited. 